\title{
Cyclophosphamide-VAD Regimen
}

National Cancer Institute

\section{Source}

National Cancer Institute. Cyclophosphamide-VAD Regimen. NCI Thesaurus. Code C64725.

A regimen consisting of vincristine, doxorubicin and dexamethasone, used as induction treatment for plasma cell myeloma. 